\title{
Farmakoterapia skojarzona w heterozygotycznej rodzinnej hipercholesterolemii
}

\author{
Combined drug therapy in heterozygous familial hypercholesterolemia
}

\author{
Longina Kłosiewicz-Latoszek, Barbara Cybulska \\ Instytut Żywności i Żywienia w Warszawie
}

\section{Streszczenie}

Rodzinna hipercholesterolemia (FH) charakteryzuje się wysokim stężeniem cholesterolu frakcji LDL (LDL-C) w osoczu i dużym ryzykiem przedwczesnej choroby wieńcowej (CHD). Heterozygotyczna rodzinna hipercholesterolemia jest najczęściej występującą chorobą genetyczną. Jej częstość ocenia się na 1/200-1/500 w populacji generalnej (w polskiej dorosłej populacji 1/250). Większość przypadków FH jest nadal niezdiagnozowana i nieleczona lub niewłaściwie leczona. Wczesne wykrycie FH i wczesne rozpoczęcie terapii mogą zmniejszyć ryzyko sercowo-naczyniowe. Intensywna terapia statyną powinna być standardem postępowania w FH. Osoby, które stosując maksymalną tolerowaną dawkę statyny, nie mogą osiągnąć docelowego stężenia LDL-C lub które nie tolerują statyn, mogą potrzebować dodatkowych lub alternatywnych leków zmniejszających stężenie lipidów. W takich sytuacjach należy rozważyć stosowanie ezetimibu i/lub inhibitorów PCSK9 jako leków dodatkowych lub w monoterapii. Wykazano, że ezetimib dodany do statyny może dodatkowo zmniejszyć ryzyko chorób sercowo-naczyniowych. Ostatnie badania z inhibitorami PCSK9, łącznie z metaanalizami, wiążą się z oczekiwaniami redukcji ryzyka epizodów sercowo-naczyniowych i zgonów. W artykule dokonano przeglądu literatury i opinii ekspertów na temat skojarzonej terapii lekowej w FH.

Słowa kluczowe: rodzinna hipercholesterolemia, ryzyko sercowo-naczyniowe, farmakoterapia skojarzona, statyny, ezetimib, inhibitory PCSK9

Folia Cardiologica 2016; 11, 5: 401-408

\section{Wstęp}

Rodzinna hipercholesterolemia ( $\mathrm{FH}$, familial hypercholesterolemia) jest genetycznym zaburzeniem charakteryzującym się znacznym podwyższeniem stężenia cholesterolu LDL (LDL-C, low-density lipoprotein cholesterol) i przedwczesną chorobą niedokrwienną serca. Zasady diagnostyki i postępowania w tej najczęściej występującej w populacji chorobie genetycznej zostały niedawno zwięźle przedstawione przez polskich ekspertów [1-3]. Powodem napisania tego artykułu są wprowadzenie do praktyki nowych silnych leków hipolipemizujących oraz publikacja nowych wytycznych uwzględniających terapię skojarzoną w rodzinnej heterozygotycznej hipercholesterolemii [4-6].

Rozróżnia się dwie postaci FH - heterozygotyczną i homozygotyczną - które różnią się objawami, stopniem ryzyka sercowo-naczyniowego i sposobami leczenia. Postać homozygotyczna występuje rzadko, szacuje się, że jest to 1 przypadek na 160 000-300 000 osób w populacji. W pracy skoncentrowano się na znacznie częściej występującej heterozygotycznej $\mathrm{FH}$, która według nowych badań może dotyczyć 1 przypadku na 200-500 osób w populacji. W Europie ocenia się, że może to być $4,5 \mathrm{mln}$ osób, a na świecie nawet $25 \mathrm{mln}[4,7]$. W Polsce, jak wynika z ostatnich badań 
Pająka i wsp. [8], częstość tej choroby oszacowano jako 1 przypadek na 250 osób. Wyniki uzyskano z metaanalizy obejmującej 6 badań z udziałem 39768 osób (47,8\% mężczyzn) w wieku 20-79 lat. Rozpoznanie opierano na kryteriach Dutch Lipids Clinics Network (DLCN) [1, 4].

Najczęstszą przyczyną FH w kolejności występowania są mutacje trzech genów: genu receptora LDL ( 79\%), genu apolipoproteiny $B(\mathrm{apoB})(\sim 5 \%)$ lub genu konwertazy proproteinowej subtiliziny/keksyny typu 9 (PCSK9, protein convertase subtilisin kexin 9) $(<1 \%)$ [9]. Odsetki te dotyczą rozpoznań na podstawie badań genetycznych. Jednak u części pacjentów mutacje genetyczne nie są znane. Nieprawidłowa struktura receptorów LDL lub apoB zaburza wiązanie lipoprotein zawierających apoB z receptorami. Skutkiem tego jest upośledzenie katabolizmu lipoprotein LDL w wątrobie. Z kolei obecność mutacji genu PCSK9 wiąże się ze zwiększoną aktywnością degeneracyjną białka PCSK9 w stosunku do receptorów LDL (low-density lipoprotein) [6].

\section{Ryzyko choroby niedokrwiennej serca}

Rodzinna hipercholesterolemia, jak już wspomniano, wiąże się z dużym ryzykiem wystąpienia przedwczesnej choroby niedokrwiennej serca (IHD, ischemic heart disease). Stężenie LDL-C jest już od urodzenia 2-3-krotnie większe niż u osób bez FH. To wyjaśnia wczesny początek subklinicznej miażdżycy tętnic wieńcowych u tych pacjentów. Z ekstrapolacji na wiek akumulacji blaszek miażdżycowych (angiografia komputerowa) wynika, że w FH ich rozwój rozpoczyna się u mężczyzn i u kobiet odpowiednio około 20. i 30. roku życia [10]. Natomiast ekstrapolacja wyników koronarograficznych (indeks stenozy wieńcowej) wskazuje, że proces ten może zachodzić jeszcze wcześniej, ponieważ zwężenie tętnic wieńcowych zaczyna się u mężczyzn w wieku 17, a kobiet w wieku 20 lat [11]. U nieleczonych osób ryzyko IHD jest 20-krotnie większe niż u osób bez FH, zwłaszcza u mężczyzn [7]. Oszacowano, że u kobiet nieleczonych w wieku 60 lat wynosi ono 30\%, a u mężczyzn w wieku 50 lat jest na poziomie $50 \%$. W innym ostatnio opublikowanym badaniu wykazano, że ryzyko wystąpienia choroby niedokrwiennej serca u osób z FH, w stosunku do populacji ogólnej, zostało przyspieszone u mężczyzn o 10-20 lat, a u kobiet o 20-30 lat [12]. Z obserwacji przeprowadzonych w okresie przedstatynowym wynika, że u osób ze zdiagnozowaną FH pierwsze objawy choroby niedokrwiennej serca występowały u mężczyzn w wieku $42 \pm 7$ lat, a u kobiet $48 \pm 11$ lat, co przekładało się na występowanie ostrego zespołu wieńcowego, odpowiednio, w wieku $47 \pm 12$ i $52 \pm 13$ lat [13]. W ostatnio opublikowanej analizie obejmującej 14 badań z lat 2004-2015 wykazano, że ryzyko IHD (iloraz szans [OR, odds ratio]) wynosiło 10,3 (95-proc. przedział ufności [Cl, confidence interval] 7,8-13,8) u chorych leczonych lekami hipoli- pemizującymi z powodu FH i 13,2 (95\% Cl 10,0-17,4) u nieleczonych tymi lekami w porównaniu z osobami bez tej choroby [14].

Niestety, obserwacje przeprowadzone w wielu krajach wskazują, że zarówno rozpoznanie $\mathrm{FH}$, jak i leczenie są niewystarczające. W badaniu obejmującym 22 kraje stwierdzono, że w większości z nich rozpoznanie $\mathrm{FH}$ wynosiło poniżej 1\% wszystkich przypadków, w 5 krajach przekraczało $5 \%$, a jedynie w Holandii było na poziomie $71 \%$ wykrywalności [4]. W badaniu EUROASPIRE IV z udziałem 24 państw wykazano, że 45\% pacjentów z FH i IHD nie otrzymywało intensywnej terapii statynowej [15]. W amerykańskim rejestrze CASCADE-FH obejmującym 11 klinik lipidowych ( $n=1295$ dorosłych pacjentów) okazało się, że tylko $42 \%$ chorych było intensywnie leczonych statyną. Spośród tych, którzy otrzymali terapię hipolipemizującą, stężenie LDL-C poniżej 100 mg/dl osiągnęło około 25\%, a u $41 \%$ uzyskano redukcję LDL-C o 50\% [16, 17]. Z ostatnio opublikowanej przez Pająka i wsp. [8] metaanalizy dotyczącej polskiej populacji wynika, że u osób z potencjalną FH (> 5 pkt. wg DLCN) leki hipolipemizujące przyjmowało 14,1\%, a w grupie pacjentów z możliwą FH (3-5 pkt. wg DLCN) - 16,9\%. Średnie stężenia cholesterolu całkowitego wynosiły, odpowiednio, $8,7 \mathrm{mmol} / \mathrm{l}$ i 6,8 $\mathrm{mmol} / \mathrm{l}$, a stężenie LDL-C - 6,4 mmol/l i 4,6 mmol/I.

\section{Farmakoterapia}

\section{Statyny}

Leczenie hipolipemizujące, co głównie wykazano w badaniach kohortowych, badaniach przekrojowych i analizach klinicznych post-hoc, powoduje redukcję incydentów sercowo-naczyniowych u pacjentów z FH. W długotrwającym (średnio 8,5 roku) badaniu kohortowym u pacjentów leczonych simwastatyną w średniej dawce $33 \mathrm{mg} /$ dobę ( $n=1167$ ) lub atorwastatyną w średniej dawce $49 \mathrm{mg} /$ /dobe ( $n=211$ ) wystąpiła redukcja LDL odpowiednio o $44 \%$ (odchylenie standardowe [SD, standard deviation] 16\%) i 49\% (SD 15\%), w stosunku do wartości wyjściowej [18]. Ryzyko wystąpienia choroby wieńcowej u osób leczonych, w porównaniu z osobami nieleczonymi, było mniejsze o 76\% (współczynnik ryzyka [HR, hazard ratio]: 0,24; 95\% Cl 0,18-0,30). Z kolei w badaniu kohortowym Simone Broome Register stwierdzono, że wprowadzenie statyn do leczenia FH wiązało się ze znamienną redukcją zgonów wieńcowych o 48\% w prewencji pierwotnej i o 23\% w prewencji wtórnej [19]. W innym badaniu analizowano ryzyko zgonu wieńcowego u pacjentów z FH w wieku 20-59 lat przed 1992 rokiem, czyli przed wprowadzeniem statyn do praktyki, i po tym roku [20]. Stwierdzono zmniejszenie ryzyka zgonu wieńcowego z 8-krotnie większego, w stosunku do populacji generalnej, przed rokiem 1992 do 3,7-krotnie większego po 1992. Podobne efekty obserwowano u leczonych pacjentów z FH rejestrowanych w poszczególnych krajach [21]. 
Należy podkreślić, że odpowiednia terapia hipolipemizująca w FH, dotychczas oparta głównie na badaniach ze statynami, dowodzi, że zmniejszenie stężenia LDL-C u tych chorych wiąże się nie tylko z redukcją incydentów sercowo-naczyniowych, ale także zgonów ogółem, czyli może wpływać na okres przeżycia pacjentów [18, 22].

U pacjentów z FH podstawowym lekiem hipolipemizującym jest silna statyna w maksymalnej dawce, czyli atorwastatyna w dawce 40-80 mg bądź rosuwastatyna w dawce 20-40 mg/dobę [1, 6]. Jednak nawet przy zastosowaniu silnych statyn rzadko można osiągnąć docelowe stężenia LDL-C, które u osób bez choroby sercowo-naczyniowej powinny być niższe niż $100 \mathrm{mg} / \mathrm{dl}(<2,5 \mathrm{mmol} / \mathrm{l})$, a u pacjentów z chorobą mniejsze niż $70 \mathrm{mg} / \mathrm{dl}(<1,8 \mathrm{mmol} / \mathrm{l})$ $[1,23,24]$. Odpowiedź na leczenie statynami jest bardzo zróżnicowana (redukcja stężenia LDL-C w zakresie 5-70\%), co może się wiązać między innymi z typem mutacji receptora LDL bądź mutacji genu PCSK9, a także z nietolerancją bądź działaniem niepożądanym [25]. Szacuje się, że 4-10\% osób może być zakwalifikowanych jako słabo bądź w ogóle niereagujące na statynę, co określa się jako redukcję LDL-C poniżej 10\% [25]. Stosowanie maksymalnych dawek statyn nie jest dobrze tolerowane przez część pacjentów, a ponadto podwojenie dawek daje mały dodatkowy efekt (redukcja LDL-C o 6\%), co ogranicza efektywność statyn w ciężkiej FH. Objawy mięśniowe podczas stosowania statyn ( 5-10\% leczonych) prowadzą niekiedy do odstawienia leku, co - jak wiadomo - zwiększa ryzyko incydentów sercowo-naczyniowych [26].

Badania wskazują, że terapia statyną zwiększa stężenie PCSK9, co może mieć wpływ na efekty leczenia [25, 27]. Gen PCSK9 jest wysokopolimorficzny, z wariantem braku bądź nadmiarem jego funkcji. Mutacja z nadmierną funkcją prowadzi do wzrostu stężenia LDL-C i występowania FH. W ostatniej metaanalizie 17 badań wykazano, że polimorfizm PCSK9 E670G łączy się z wyższym stężeniem LDL-C i większym ryzykiem chorób układu sercowo-naczyniowego (CVD, cardiovascular disease) [28]. Z kolei mutacja genu PCSK9 z brakiem funkcji wiąże się ze stężeniem LDL-C mniejszym o 15-30\% i dramatycznie mniejszym ryzykiem (50-90\%) incydentów sercowo-naczyniowych w ciągu 15 lat obserwacji [29].

U osób, u których nie uzyskano celów leczenia dla LDL-C bądź redukcji co najmniej 50\%, zaleca się rozważenie terapii skojarzonej. Zgodnie z ostatnimi wytycznymi do statyny najpierw należy dodać ezetimib (terapia dwulekowa), a w kolejnym etapie można rozważyć dodanie inhibitora PCSK9 (terapia trójlekowa) [1, 6, 30]. W przypadku nietolerancji statyn można zastosować te leki w monoterapii. Eksperci uznają też zastosowanie innych leków niestatynowych, czyli żywic, bądź kwasu nikotynowego oraz nowych leków (mipomersen, lomitapid) w skojarzeniu ze statyną dla osiągnięcia celu leczenia lub w monoterapii, jeśli pacjent nie toleruje statyn. Żywice i kwas nikotynowy są w Polsce niedostępne i z tego powodu nie zostały omówione w pracy. W homozygotycznej FH stosuje się mipomersen i lomitapid. Ten pierwszy nie został zarejestrowany w Europie ze względu na poważne działania niepożądane. Wpływ leków pozastatynowych na redukcję stężenia lipoprotein przedstawiono w tabeli 1.

\section{Ezetimib}

Ezetimib hamuje białko NPC1L1 (Niemann-Pick C1-like 1 transporter protein) w erytrocytach jelita, co prowadzi do zmniejszenia wchłaniania cholesterolu [31, 32]. Wykazano, że zmniejsza się ono o około $50 \%$, co prowadzi do

Tabela 1. Leki hipolipemizujące u pacjentów z rodzinną hipercholesterolemią (wg [17], modyfikacja własna)

\begin{tabular}{|c|c|c|c|c|c|c|}
\hline & Leki & Dawka & $\begin{array}{c}\text { LDL-C } \\
\Delta \%\end{array}$ & $\begin{array}{c}\text { HDL-C } \\
\Delta \%\end{array}$ & $\begin{array}{c}\text { TG } \\
\Delta \%\end{array}$ & $\begin{array}{l}\operatorname{Lp}(\mathrm{a}) \\
\Delta \%\end{array}$ \\
\hline \multirow{7}{*}{$\begin{array}{l}\text { Postać } \\
\text { heterozygo- } \\
\text { tyczna }\end{array}$} & Ezetimib & $10 \mathrm{mg} / \mathrm{d}$. & -17 do -25 & 0 do 5 & -7 do -10 & -10 do -20 \\
\hline & Niacyna & $1,5-2 \mathrm{~g} / \mathrm{d}$ & -15 do -20 & 22 do 30 & -29 do -40 & -20 do -30 \\
\hline & Żywice & & -5 do -28 & 0 do 3 & 0 do 10 & 2 do 10 \\
\hline & Alirokumab* & 75-150 mg/2 tyg. & -63 do -45 & 6 do 9 & -30 do -25 & -30 do -25 \\
\hline & Ewolokumab* & 140 mg/2 tyg. & -65 do -50 & 2 do 11 & -21 do 0 & -28 do -17 \\
\hline & & 420 mg/mies. & & & & \\
\hline & Afereza & Co 2 tyg. & -82 do -54 & -27 do -7 & -34 do -49 & -72 do -51 \\
\hline \multirow{3}{*}{$\begin{array}{l}\text { Postać } \\
\text { homozygo- } \\
\text { tyczna }\end{array}$} & Ewolokumab* & 420 mg/mies. & -32 do 15 & -2 do -10 & -11 do 8 & -18 do -1 \\
\hline & Mipomersen* $* *$ & 200 mg/160 mg/tydz. & -36 do -18 & 3 do 27 & -36 do -4 & -39 do -21 \\
\hline & Lomitapid** & $10-60 \mathrm{mg}$ & -52 do -24 & -13 do 3 & -54 do -8 & -17 do 1 \\
\hline
\end{tabular}

*Leki podawane podskórnie; **leki stosowane w bardzo ciężkiej postaci rodzinnej hipercholesterolemii; LDL-C (low-density lipoprotein cholesterol) - cholesterol frakcji lipoprotein o niskiej gęstości; HDL-C (high-density lipoprotein cholesterol) - cholesterol frakcji lipoprotein o wysokiej gęstości; TG - triglicerydy; Lp(a) - lipoproteina(a) 
zwiększenia ekspresji receptorów dla cholesterolu frakcji LDL na powierzchni hepatocytów. W monoterapii ezetimib zmniejsza stężenie LDL-C o 17-25\%, triglicerydów o 7-10\% oraz zwiększa stężenie cholesterolu frakcji HDL (HDL-C, high-density lipoprotein cholesterol) do 5\% (tab. 1), natomiast w leczeniu skojarzonym ze statyną powoduje dalszą redukcję LDL-C o 14-25\%, triglicerydów o 7,5-14\% oraz wzrost HDL-C o 2-3\% [17, 32]. W badaniu pod akronimem ACTE (The EfficACy and SafeTy of Ezetimibe Added On to Rosuvastatin Versus Up-Titration of Rosuvastatin in Hypercholesterolemic Patients at Risk for Coronary Heart Disease) stwierdzono, że podwojenie dawki rosuwastatyny z $10 \mathrm{mg}$ do $20 \mathrm{mg} /$ dobę powoduje jedynie redukcję LDL-C o 5,7\%, natomiast dodanie ezetimibu do rosuwastatyny w dawkach $10 \mathrm{mg}$ lub $20 \mathrm{mg} /$ dobe prowadzi do spadku stężenia tego lipidu o 21\% [33]. W porównaniu ze zwiększaniem dawki rosuwastatyny dodanie ezetimibu wiązało się ze znamiennie większym osiągnięciem stężenia LDL poniżej 70 mg/dl (43,8\% v. 17,5\%) i mniej niż 100 mg/dl (59,4\% v. 30,9\%). Z kolei w innych badaniach po zastosowaniu simwastatyny i ezetimibu u pacjentów z FH uzyskano redukcję LDL-C średnio o 57\%, niezależną od mutacji receptora LDL [34], a najwyższe wartości redukcji dochodziły nawet do $70 \%$ [35]. W innym badaniu przeprowadzonym także u pacjentów z FH podawanie atorwastatyny z ezetimibem ( $n=255$ ) spowodowało redukcje LDL-C o 54,5\%. Po samej atorwastatynie ( $n=248$ ) LDL-C zmniejszyło się o 42,6\%, a po samym ezetimibie $(n=65)$ o $18,4 \%$ [36]. Zmiany w stężeniach triglicerydów wynosiły, odpowiednio, $-32,8 \%$, $-24,5 \%,-5,1 \%$, a w stężeniach HDL-C 7,3\%, 4,3\% i 4,2\%. Wszystkie różnice były statystycznie istotne $(p<0,01)$.

Wiadomo, że głównym uzasadnieniem stosowania leków hipolipemizujących jest zmniejszenie występowania incydentów sercowo-naczyniowych. Pierwszym badaniem dokumentującym wpływ ezetimibu na obniżenie ryzyka sercowo-naczyniowego było badanie SHARP (Study of Heart and Renal Protection), w którym uczestniczyło 9438 pacjentów z przewlekłą chorobą nerek [37]. U chorych przyjmujących ezetimib $(10 \mathrm{mg} / \mathrm{d}$.) w połączeniu z simwastatyną ( $20 \mathrm{mg} / \mathrm{d}$.) w czasie 4,9 roku obserwacji, w porównaniu z grupą przyjmującą placebo, stwierdzono o 17\% (95\% Cl 0,74-0,94; p = 0,0021) mniej poważnych incydentów naczyniowych (zawały serca, udary mózgu, zabiegi rewaskularyzacyjne). Największym badaniem ( $n$ = 18144 pacjentów po ostrym zespole wieńcowym), dokumentującym większą redukcję incydentów sercowo-naczyniowych podczas leczenia skojarzonego simwastatyną (40 mg/d.) i ezetimibem (10 mg/d.), w porównaniu z monoterapią simwastatyną (40 mg/d.), jest IMPROVE-IT (The Improved Reduction of Outcomes: Vytorin Efficacy International Trial) [38]. Terapia skojarzona pozwoliła osiągnąć mniejsze stężenie LDL-C (średnio 53,7 mg/dl v. $69,5 \mathrm{mg} / \mathrm{dl})$ oraz istotnie większą redukcję $(6,4 \% ; \mathrm{p}=$ = 0,016) częstości występowania złożonego punktu koń- cowego (tj. zgon z przyczyn sercowo-naczyniowych, zawał serca, niestabilna dławica piersiowa wymagająca hospitalizacji, ponowna rewaskularyzacja lub udar mózgu niezakończony zgonem). Częstość występowania działań niepożądanych w obu grupach była porównywalna.

Warto dodać, że w badaniu pod akronimem ZEUS (eZetimibe Ultrasound Study) przeprowadzonym u pacjentów z ostrym zespołem wieńcowym $(n=35)$ dodanie ezetimibu (10 mg) do atorwastatyny (20 mg), wiązało się z większą redukcją LDL-C $(-49,8 \%$ v. $-34,6 \% ; p=0,016)$ oraz większą regresją w objętości blaszki miażdżycowej [39]. Procentowe zmiany objętości wynosiły odpowiednio 12,5\% w porównaniu $z 7,6 \%(p=0,06)$. Podobne wyniki uzyskano w innym ostatnio opublikowanym badaniu PRECISE-IVUS (Plaque REgression with Cholesterol absorption Inhibitor or Synthesis inhibitor Evaluated by IntraVascular UItraSound) [40]. Dodanie ezetimibu do atorwastatyny, w porównaniu z monoterapią statyną, wiązało się z większą redukcją stężenia cholesterolu całkowitego, LDL-C, triglicerydów, remnantów oraz redukcją małych gęstych cząsteczek LDL, a także regresją blaszki miażdżycowej. W świetle tych badań można oczekiwać, że zastosowanie terapii skojarzonej w FH może również wiązać się z korzystnym „wpływem” na ścianę naczyń, ale niezbędne są dalsze badania kliniczne w tym zakresie.

Mimo że nie przeprowadzono badań oceniających wybiórczo efekty kliniczne terapii skojarzonej statyną i ezetimibem u chorych z rodzinną hipercholesterolemią, należy przypuszczać na podstawie dotychczas przeprowadzonych badań, że większej redukcji LDL-C towarzyszy większa redukcja incydentów sercowo-naczyniowych. Wyniki badań potwierdzają słuszność stosowania w terapii hipolipemizującej zasady „im niżej, tym lepiej”. Ostatnie analizy wskazują, że stosowanie ezetimibu jest skuteczne i bezpieczne [31, 32]. Dotyczy to również wcześniejszych doniesień (badanie SEAS [Simvastatin and Ezetimibe in Aortic Stenosis]), że w czasie terapii tym lekiem wzrasta ryzyko raka [41], ponieważ metaanaliza obejmująca 20617 pacjentów z badań SHARP i IMPROVE-IT wykazała brak istotnych różnic w występowaniu nowotworów w grupie leczonej simwastatyną i ezetimibem w porównaniu z grupa leczoną samą simwastatyną. Liczba przypadków nowotworów wynosiła odpowiednio 313 i 326 (ryzyko względne [RR, relative risk] 0,96; 95\% $\mathrm{Cl}: 0,82-1,12 ; \mathrm{p}=0,61$ ) [42].

\section{Inhibitory PCSK9}

W ostatniej dekadzie prowadzone są badania kliniczne z nową grupa leków hipolipemizujących - inhibitorami PCSK9 [2, 43-45]. Enzym PCSK9, wiążąc się z receptorami LDL w lizozomie hepatocytów, powoduje degradację receptorów. Zatem hamowanie aktywności PCSK9 zwiększa aktywność receptora LDL, co w konsekwencji prowadzi do zmniejszenia stężenia LDL-C w surowicy. Stosując inhibitory PCSK9, można uzyskać redukcję LDL-C do 60\%, niezależnie od terapii statynami. 
Tabela 2. Inhibitory PCSK9 w badaniach klinicznych u pacjentów z rodzinną hipercholesterolemią (wg [43], zmodyfikowane)

\begin{tabular}{|c|c|c|c|c|c|c|c|c|c|}
\hline Badanie & Lek & Czas & $\mathrm{n}$ & Kryteria & Dawka & LDL-C & HDL-C & $\mathrm{TG}$ & $\operatorname{Lp}(a)$ \\
\hline \multirow[t]{2}{*}{ RUTHEFORD } & Ewolokumab & 12 tyg. & 168 & LDL-C $\geq 100 \mathrm{mg} / \mathrm{dl}$ & 350 mg/4 tyg. & -44 & +8 & -15 & -23 \\
\hline & & & & Statyna \pm ezetimib & 420 mg/4 tyg. & -56 & +7 & -20 & -32 \\
\hline \multirow[t]{2}{*}{ RUTHEFORD-2 } & Ewolokumab & 12 tyg. & 331 & LDL-C $\geq 100 \mathrm{mg} / \mathrm{dl}$ & 140 mg/2 tyg. & -59 & +9 & -20 & -32 \\
\hline & & & & Statyna \pm inne leki & 420 mg/4 tyg. & -61 & +9 & -12 & -28 \\
\hline ODYSSEY FHI & Alirokumab & 24 tyg. & 483 & $\begin{array}{c}\text { LDL-C } \geq 100 \mathrm{mg} / \mathrm{dl} \text { bez CVD } \\
\text { lub LDL-C > } 70 \mathrm{mg} / \mathrm{dl} \mathrm{z} \mathrm{CVD} \\
\text { na maks. dawce statyny } \\
\text { i inny lek hipolipemizujący }\end{array}$ & 75 mg/2 tyg. & -58 & - & - & - \\
\hline ODYSSEY FHII & Alirokumab & 24 tyg. & 249 & JW. & 75 mg/2 tyg. & -51 & - & - & - \\
\hline $\begin{array}{l}\text { ODYSSEY } \\
\text { High FH }\end{array}$ & Alirokumab & 24 tyg. & 107 & $\begin{array}{c}\text { Maks. tolerowana dawka } \\
\text { statyny i inny lek hipolipe- } \\
\text { mizujący }\end{array}$ & 150 mg/2 tyg. & -39 & - & - & - \\
\hline
\end{tabular}

LDL-C (low-density lipoprotein cholesterol) - cholesterol frakcji lipoprotein o niskiej gętości; HDL-C (high-density lipoprotein cholesterol) - cholesterol frakcji lipoprotein o wysokiej gęstości; TG - triglicerydy; Lp(a) - lipoproteina(a); CVD (cardiovascular disease) - choroby układu sercowo-naczyniowego

Spośród inhibitorów PCSK9 dwa leki zarejestrowały Europejska Agencja Leków (EMA, European Medicines Agency) i Agencja Żywności i Leków (FDA, Food and Drug Administration) [2, 17]. Są to ewolokumab i alirokumab. W badaniach klinicznych III fazy znajduje się bokocizumab, natomiast inne leki z tej grupy są w II fazie (AGT-209, RG-7652), I fazie (ALN-PCS02, BMS-962476) oraz w badaniach przedklinicznych (TBD, Id05-IgG2, IDI E67-AB pepside fragment) [44]. Wskazaniami do stosowania inhibitorów PCSK9 są rodzinna hipercholesterolemia, nietolerancja statyn oraz wysokie ryzyko u pacjentów, którzy mimo stosowania maksymalnych dawek statyn nie osiągają celów leczenia [2, 6, 17, 30].

\section{Ewolokumab}

Efekty działania ewolokumabu u pacjentów z heterozygotyczną postacią FH oceniano w badaniach: RUTHERFORD (The Reduction of LDL-C with PCSK9 Inhibition in Heterozygous Familial Hypercholesterolemia Disorder) i RUTHERFORD-2 [46, 47]. W pierwszym z nich uczestniczyło 167 chorych ze stężeniem LDL-C co najmniej 2,6 mmol// ( $\geq 100 \mathrm{mg} / \mathrm{dl}$ ), mimo leczenia maksymalną dawką statyny. Pacjentów podzielono na 3 grupy, w których co 4 tygodnie dodawano do statyny ewolokumab podskórnie w dawce 350 mg lub 420 mg lub placebo (łącznie 12 tygodni leczenia). U chorych leczonych statyną i ewolokumabem stwierdzono średnią znamienną redukcję LDL-C, odpowiednio, o 43\% i 55\% w stosunku do stężeń osiągniętych podczas leczenia statyną i placebo. Z kolei w badaniu RUTHERFORD-2 oceniano efekty ewolokumabu w skojarzeniu $z$ innymi lekami hipolipemizującymi. W badaniu uczestniczyło 331 pacjentów, którzy nie osiągnęli celów leczenia mimo stosowania maksymalnej dawki statyny podawanej w monoterapii lub w skojarzeniu z ezetimibem. Ewolokumab badani przyjmowali w dawce $140 \mathrm{mg}$ co 2 tygodnie lub $420 \mathrm{mg}$ co miesiąc lub placebo przez 12 tygodni. W grupie kontrolnej podawano placebo. Stwierdzono średnią redukcję LDL-C odpowiednio o 59,2\% w porównaniu z 61,3\% w grupach leczonych, a LDL-C poniżej $70 \mathrm{mg} / \mathrm{dl}$ osiągnęło 68\% i 63\% pacjentów. Wystąpił również korzystny wpływ ewolokumabu na inne lipidy (tab. 2). Obserwowano redukcję stężeń Apo B o 49\% i nie-HDL-C o 54,8\%.

Nie ma wprawdzie badania z ewolokumabem w rodzinnej hipercholesterolemii, w którym oceniano by wpływ tego leku na występowanie epizodów sercowo-naczyniowych, jest dostępna natomiast otwarta obserwacja kliniczna OSLER (Open-Label Study of Long-Term Evaluation against LDL cholesterol), w której dobrowolnie uczestniczyli pacjenci z badań II i III fazy z tym lekiem (monoterapia lub terapia skojarzona ze statyną) [48]. Roczne leczenie ewolokumabem (+ standardowe leczenie hipolipemizujące, w porównaniu ze standardowym leczeniem + placebo) spowodowało redukcję występowania epizodów sercowo-naczyniowych o 53\% (95\% Cl: 0,22-0,71).

\section{Alirokumab}

Efekty stosowania alirokumabu u pacjentów z rodzinną hipercholesterolemią oceniano w ramach programu ODYSSEY (ODYSSEY-FH I, II, HIGH FH i LONG-TERM) [49-52]. W badaniach ODYSSSEY FH I $(n=483)$ i FH II $(n=249)$ pacjentom przyjmującym maksymalną dawkę statyny podawano co 2 tygodnie alirokumab w dawce $75 \mathrm{mg}$. Wyjściowe LDL-C wynosiło w pierwszym badaniu około $145 \mathrm{mg} / \mathrm{dl}$, a w drugim około 135 mg/dl. Po 24 tygodniach stwierdzono średnią znamienną redukcję LDL-C o 58\% i 51\%, w porównaniu z placebo. Wyniki utrzymywały się także w 52 tygodniu terapii. W badaniu ODYSSEY HIGH FH uczestniczyło 107 pacjentów ze stężeniem LDL-C co najmniej 160 mg/dl, stosujących maksymalnie tolerowaną dawkę statyny \pm inne leki hipolipemizujące. Po 
24 tygodniach terapii (alirokumab w dawce $150 \mathrm{mg}$ co 2 tygodnie) stężenie LDL-C znamiennie zmniejszyło się o 46\%, a w grupie placebo - o 7\%. Różnica wynosiła zatem $39 \%$ i utrzymywała się w 52 tygodniu leczenia. Cholesterol frakcji LDL poniżej $70 \mathrm{mg} / \mathrm{dl}$ osiągnęło 32\% stosujących alirokumab i 3\% przyjmujących placebo.

W badaniu ODYSSEY LONG TERM uczestniczyło 2341 pacjentów z heterozygotyczną postacią FH (18\%) lub rozpoznaną IHD, leczonych głównie statyną (47\% maksymalną dawką, 14\% ezetimibem). Alirokumab w dawce 150 mg co 2 tygodnie przyjmowało 1553 chorych, a 788 stosowało placebo. W stosunku do wyjściowej wartości stężenia LDL-C (średnia $122 \mathrm{mg} / \mathrm{dl}$ ) uzyskano jego znamienną średnią redukcję o $62 \%$ w 24. tygodniu leczenia i o 61\% w 52 . tygodniu terapii. U pacjentów z FH redukcja w 24. tygodniu wynosiła $63 \%$. W analizie post hoc u wszystkich leczonych alirokumabem po 78 tygodniach stwierdzono mniej o 48\% (95\% Cl 10-69) złożonych incydentów (zgon wieńcowy, zawał bez zgonu, udar niedokrwienny z i bez zgonu i niestabilna dławica wymagająca hospitalizacji) w porównaniu z placebo [51, 52].

Ostatnio w metaanalizach wykazano korzystny związek stosowania inhibitorów PCSK9 z danymi na temat zgonów ogółem i zgonów sercowo-naczyniowych [53, 54]. Do metaanalizy obejmującej 24 próby kliniczne z udziałem 10159 osób włączono 12 badań wśród pacjentów z FH, 9 wśród chorych z nierodzinną i nieokreśloną hipercholesterolemią, 2 badania wśród osób nietolerujących statyn i jedno badanie nad rodzinną i nierodzinną hipercholesterolemią łącznie. W grupach kontrolnych stosowano placebo lub ezetimib. W wyniku terapii inhibitorem PCSK9 we wszystkich próbach klinicznych łącznie stwierdzono istotne zmniejszenie zgonów ogółem o 55\% (OR 0,45; 95\% Cl 0,23-0,86) oraz nieznamienną redukcję zgonów sercowo-naczyniowych o 50\% (OR 0,50; 95\% Cl
0,23-1,10) [53]. Stwierdzono także znamienne zmniejszenie występowania zawałów serca o 51\% - dane pochodziły z 10 badań z udziałem 5195 pacjentów. Średnia redukcja LDL-C w wyniku stosowania inhibitorów PCSK9 wynosiła $47,5 \%$ w porównaniu z grupą kontrolną. Nie stwierdzono poważnych działań niepożądanych u pacjentów leczonych w porównaniu z chorymi z grupy kontrolnej. Czas trwania poszczególnych badań był zróżnicowany i wynosił mniej niż 6 miesięcy w 16 spośród nich, 6-12 miesięcy w 2 badaniach, a w pozostałych dłużej niż rok.

W kolejnej metaanalizie obejmującej 17 badań klinicznych z udziałem 13083 pacjentów z pierwotną hipercholesterolemią stwierdzono, że stosowanie inhibitorów PCSK9 wiązało się ze znamiennym zmniejszeniem zgonów ogółem o 57\% (OR 0,43; 95\% Cl 0,22-0,82) [54]. Redukcja, choć nieznamienna, dotyczyła także zgonów sercowo-naczyniowych o 50\% (OR 0,50; 95\% Cl 0,22-1,13) i epizodów sercowo-naczyniowych o 33\% (OR 0,67; 95\% Cl 0,43-1,04). Inhibitory PCSK9 przyczyniły się do znamiennego zmniejszenia LDL-C średnio o 57\% w porównaniu z placebo i o 36,1\% w stosunku do ezetimibu. W tej metaanalizie stwierdzono jednak istotny wzrost objawów zaburzeń neuropoznawczych w porównaniu z placebo.

W świetle tych badań i metaanaliz uzasadniona jest zatem konieczność prowadzenia dalszych obserwacji dotyczących wpływu terapii inhibitorem PCSK9 na ryzyko sercowo-naczyniowe, jak również ewentualnych działań niepożądanych. W toku są badania z ewolokumabem (FOURIER), alirokumabem (ODYSSEY OUTCOMES) i bokocizumabem (SPIRE1 i SPIRE2) [45].

Jak wynika z przeglądu, terapia skojarzona - dodanie ezetimibu i/lub inhibitora PCSK9 do statyny - pozwala większej liczbie pacjentów z FH osiągnąć docelowe stężenie LDL-C, co może mieć wpływ na większą redukcję ryzyka sercowo-naczyniowego niż ta, która występuje w następstwie monoterapii statyną.

\section{Abstract}

Familial hypercholesterolemia (FH) is characterized by high LDL-cholesterol (LDL-C) plasma concentration that is accompanied by the high risk of premature coronary heart disease (CHD). Heterozygous familial hypercholesterolemia is the most prevalent genetic disease with an estimated prevalence of 1/200-1/500 in general population (in Polish adult population about 1/250). The majority of $\mathrm{FH}$ patients are still underdiagnosed and undertreated. Early detection of $\mathrm{FH}$ and early initiation of treatment can reduce the cardiovascular risk. High-intensity statin therapy should be the standard of care for $\mathrm{FH}$. Individuals, who cannot achieve the LDL-C target concentration on maximum tolerated dose of a statin or are statin intolerant, may require additional or alternative lipid lowering drugs. In such a situations ezetimibe and/or PCSK9 inhibitors should be considered as additional drugs or as monotherapy. It has been shown that ezetimibe added to statin therapy can reduce additionally the risk of cardiovascular diseases. The recent with PCSK9 inhibitors studies coupled with meta-analyses, show some promise in terms of reducing cardiovascular events and mortality. This article reviews current literature as well as expert opinions on combined drug therapy for $\mathrm{FH}$.

Key words: familial hypercholesterolemia, cardiovascular risk, combined pharmacotherapy, statins, ezetimibe, PCSK9 inhibitors

Folia Cardiologica 2016; 11, 5: 401-408 


\section{Piśmiennictwo}

1. Rynkiewicz A., Cybulska B., Banach M. i wsp. Postępowanie w heterozygotycznej hipercholesterolemii rodzinnej. Stanowisko Forum Ekspertów Lipidowych. Kardiol. Pol. 2013; 71: 107-111.

2. Cybulska B., Gaciong Z., Hoffman P. i wsp. Ciężka hipercholesterolemia - kiedy stosować inhibitory proproteinowej konwertazy subtilizyny/ /kexiny 9 (inhibitory PCSK9)? Stanowisko grupy ekspertów Polskiego Towarzystwa Kardiologicznego. Kardiol. Pol. 2016; 74: 394-398.

3. Myśliwiec M., Walczak M., Małecka-Tendera E. i wsp. Management of familial hypercholesterolemia in children and adolescents. Position paper of the Polish Lipid Expert Forum. J. Clin. Lipidom. 2014; 8: 173-80.

4. Nordestgaard B.G., Chapman M.J., Humphres S.E. i wsp. European Atherosclerosis Society consensus panel. Familial hypercholesterolemia is underdiagnosed and undertreatment in the general population: guidance for clinicians to prevent coronary artery disease. Eur. Heart J. 2013; 34: 3478-3490.

5. Weigman A., Gidding S.S., Watts G.F. i wsp.; for the European Atherosclerosis Society Consensus Panel. Familial hypercholesterolaemia in children and adolescents: gaining decades of life by optimizing detection and treatment. Eur. Heart J. 2015; 36: 2425-2437.

6. Santos R.D., Gidding S.S., Hegele R.A. i wsp. Defining severe familial hypercholesterolaemia and the implications for clinical management: a consensus statement from the International Atherosclerosis Society Severe Familial Hypercholesterolemia Panel. Lancet Diab. Endocrinol. 2016; 4: 850-861.

7. Onorato A., Sturm A.C. Heterozygous familial hypercholesterolemia. Circulation 2016; 133; e587-e589.

8. Pająk A., Szafraniec K., Polak M. i wsp. Prevalence of familial hipercholesterolemia: a meta-analysis of six large, observational, population-based studies in Poland. Arch. Med. Sci. 2016; 12: 687-696.

9. Henderson R., O'Kane M., Mc Gilligan V., Watterson S. The genetics and screening of familial hypercholesterolaemia. J. Biomed. Sci. 2016; 23: 39.

10. Tada H., Kawashiri M.A., Okada H. i wsp. Assesment of coronary atherosclerosis in patients with familial hypercholesterolemia by coronary computed tomography angiograpy. Am. J. Cardiol. 2015; 115: 724-729.

11. Vuorio A., Watts G.F., Kovanen P.T. Initiation of PCSK9 inhibition in patients with heterozygous familial hypercholesterolaemia entering adulthood: a new desigh for living with a high risk condition? Eur. Heart J. 2016; 37: 1359-1356.

12. Perak A.M., Ning H., de Ferranti S.D. i wsp. Long-term risk of atherosclerotic cardiovascular disease in US adults with the familial hypercholesterolemia phenotype. Circulation 2016; 134: 9-19.

13. Vuorio A.F., Turtola H., Pülahti K.M. i wsp. Familial hypercholesterolemia in the Finnish north Karelia. A molecular, clinical, and genealogical study. Arterioscler. Thromb. Vasc. Biol. 1997; 17: 3127-3138.

14. Wong B., Kruse G., Kutikova L. i wsp. Cardiovascular disease risk associated with familial hypercholesterolaemia: a systematic review of literature. Clin. Ther. 2016; 38: 1696-1709.

15. De Backer G., Besseling J., Chapman J. i wsp. Prevalence and management of familia Hipercholesterolemia in coronary patients: an analysis of EUROASPIRE IV, a study of the European Society of Cardiology. Atherosclerosis 2015; 241: 169-175.

16. de Goma E.M., Ahmad Z.S., O'Brien E.C. i wsp. Treatment gaps in adults with heterozygous familial hypercholesterolemia in the United States: data from the CASCADE-FH Registry. Circ. Cardiovasc. Genet. 2016; 9: 240-249.
17. Safarova M.S., Kullo I.J. My approach to the patients with familial hipercholesterolemia. Mayo Clin. Proc. 2016; 91: 770-786.

18. Vermissen J., Oosterveer D.M., Yazdanpanah M. i wsp. Efficacy of statins in familial hypercholesterolaemia: a long term cohort study. BMJ 2008; 337: a2423.

19. DeMott K., Nherera L., Shaw E.J. i wsp. Clinical guidelines and evidence review for familial hypercholesterolaemia: the identification and management of adults and children with familial hypercholesterolaemia. National Collaborating Centre for Primary Care and Royal College of General Practitioners, London 2008.

20. Group S.S., Cobot S.B.R. Mortality in treatment heterozygous familial hypercholesterolaemia: implications for clinical management. Atherosclerosis 1999; 142: 105-112.

21. Mundal L., Retlerstøl K. A systematic review of current studies in patients with familial hypercholesterolemia by use of national familial hypercholesterolemia registries. Curr. Opin. Lipidol. 2016; 27: 388-397.

22. Neil A., Cooper J., Betteridge J. i wsp. Reduction in all-cause, cancer, and coronary mortality in statin-treated patients with heterozygous familial hypercholesterolaemia: a prospective registry study. Eur. Heart J. 2008; 29: 2625-2633.

23. Catapano A.L., Graham I., De Backer G. i wsp. 2016 ESC/EAS Guidelines for the Management of Dyslipidaemias: the Task Force for the Management of Dyslipidaemias of the European Society of Cardiology (ESC) and European Atherosclerosis Society (EAS) Developed with the special contribution of the European Association for Cardiovascular Prevention and Rehabilitation (EACPR). Atherosclerosis 2016; 253: 281-344.

24. Piepoli M.F., Hoes A.W., Agewall S. i wsp. 2016 European Guidelines on cardiovascular disease prevention in clinical practice: The Sixth Joint Task Force of the European Society of Cardiology and Other Societies on Cardiovascular Disease Prevention in Clinical Practice (constituted by representatives of 10 societies and by invited experts). Developed with the special contribution of the European Association for Cardiovascular Prevention and Rehabilitation (EACPR). Eur. Heart J. 2016; 37: 2315-2381.

25. Taylor B.A., Thompson P.D. Statins and their effect on PCSK9 - impact and clinical relevance. Curr. Ahteroscler. Rep. 2016; 18: 46.

26. Piltman D.G., Chen W., Bowlin S.J., Foody J.M. Adherence to statin, subsequent healthcare costs, and cardiovascular hospitalizations. Am. J. Cardiol. 2011; 107: 1662-1626.

27. Wu N.Q., Li J.J. PCSK9 gene mutations and low-density lipoprotein cholesterol. Clin. Chim. Acta 2014; 438: 148-153.

28. Cai G., Zhan B., Shi G. i wsp. The associations between proprotein convertase subtilisin/kexin type $9 \mathrm{E} 670 \mathrm{G}$ polymorphism and the risk of coronary artery disease and serum lipid levels: a meta-analysis. Lipids Health Dis. 2015; 14: 149.

29. Cohen J.C., Boerwinkle E., Mosley Jr T.H., Hobbs H.H. Sequence variatrions in PCSK9, low HDL, and protection against coronary heart disease. N. Engl. J. Med. 2006; 354: 1264-1272.

30. Writing Committee; Lloyd-Jones D.M., Morris P.B., Ballantyne C.M. i wsp. 2016 ACC Expert Consensus Decision Pathway on the role of non-statin therapies for LDL-cholesterol lowering in the management of atherosclerotic cardiovascular disease risk. A Report of the American College of Cardiology Task Force on Clinical Expert Consensus Documents. J. Am. Coll. Cardiol. 2016; 68: 92-125.

31. Agarwala A., Kajani Z., Miedema M.D., Virani S.S. The role of ezetimibe in the treatment of cardiovascular disease. Curr. Atheroscler. Rep. 2016; 18: 1-8. 
32. Starzyk K., Wożakowska-Kapłon B. Gdy statyna to za mało - skojarzenie statyny $z$ ezetimibem $w$ terapii hipercholesterolemii. Folia Cardiol. 2015; 10: 428-437.

33. Bays H.E., Davidson M.H., Massaad R. i wsp. Safety and efficacy of ezetimibe addend on to rosuvastatin 5 or $10 \mathrm{mg}$ versus up-titration of rosuvastatin in patients with hyper-cholesterolemia (the ACTE Study). Am. J. Cardiol. 2011; 108: 523-530.

34. Pisciotta L., Fasano T., Bellocchio A. i wsp. Effect of ezetimibe coadministered with statins in genotype-confirmed heterozygous $\mathrm{FH}$ patients. Atherosclerosis 2007; 194: e116-e122.

35. Avellone G., DiGarbo V., Guarnotta V. i wsp. Efficacy and safety of long-term ezetimibe/simvastatin treatment in patients with familial hypercholesterolemia. Int. Angiol. 2010; 29: 514-524.

36. Ballantyne C.M., Houri J., Notarbartolo A. i wsp. Effect of ezetimibe coadministered with atorvastatin in 628 patients with primary hypercholesterolemia. A prospective, randomized, double-blind trial. Circulation 2003; 107: 2409-2415.

37. Baigent C., Landray M.J., Reith C. i wsp.; SHARP Investigators. The effects of lowering LDL cholesterol with simvastatin plus ezetimibe in patients with chronic kidney disease (Study of Heart and Renal Protection): a randomized placebo-controlled trial. Lancet 2011; 377 : 2181-2192.

38. Cannon C.P., Blazing M.A., Gingliano R.P. i wsp. IMPROVE-IT Investigators. Ezetimibe Added to Stain Therapy after Acute Coronary Syndromes. N. Engl. J. Med. 2015; 372: 2387-2397.

39. Nakajima N., Miyauchi K., Yokoyama T. i wsp. Effect of combination of ezetimibe and statin on coronary plaque regression in patients with acute coronary syndrome. ZEUS trial (eZetimibe Ultrasound Study). IJC Metab. Endocr. 2014; 3: 8-13.

40. Tsujita K., Yamanaga K., Komura N. i wsp.; PRECISE-IVUS Investigators. Lipid profile associated with coronary plaque regression in patients with acute coronary syndrome: subanalysis of PRECISE-IVUS trial. Atherosclerosis 2016; 251: 367-372.

41. Rossebo A.B., Pedersen T.R., Boman K. i wsp. Intensive lipid lowering with simvastatin and ezetimibe in aortic stenosis. N. Engl. J. Med. 2008; 359: 1343-1356.

42. Peto R., Emberson J., Landray M. i wsp. Analyses of cancer data from three ezetimibe trials. N. Engl. J. Med. 2008; 359: 1357-1366.

43. Pokharel Y., Virani S.S., Ballantyne C.M. The promise of protein convertase subtilisin/kexin 9 inhibitors for the treatment of familial hypercholesterolemia. Curr. Atheroscler. Rep. 2015; 17: 508.
44. Ito M.K., Santos R.D. PCSK9 inhibition with monoclonal antibodies: modern management of hypercholesterolemia. J. Clin. Pharmacol. 2016 May 16 [złożone do druku].

45. Latimer J., Batty J.A., Neely R.D.G., Kunadian V. PCSK9 inhibitors in the prevention of cardiovascular disease. J. Thromb. Thrombolysis 2016; 42: 405-419.

46. Raal F., Scott R., Somaratne R. i wsp. Low-density lipoprotein cholesterol-lowering effects of AMG 145, a monoclonal antibody to proprotein convertase subtilisin/kexin type 9 serine protease in patients with heterozygous familial hypercholesterolemia: the reduction of LDL-C with PCSK9 inhibition in heterozygous familial hypercholesterolemia disorder (RUTHERFORD) randomized trial. Circulation 2012; 126: 2408-2417.

47. Raal F.J., Stein E.A., Dufour R. i wsp. PCSK9 inhibition with evolocumab (AMG 145) in heterozygous familial hypercholesterolaemia (RUTHERFORD-2): a randomised, double-blind, placebo-controlled trial. Lancet 2015; 385: 331-340.

48. Sabatine M.S., Giugliano R.P., Wiviott S.D. i wsp. Efficacy and safety of evolocumab in reducing lipids and cardiovascular events. N. Engl. J. Med. 2015; 372: 1500-1509.

49. Kastelein J.J., Ginsberg H.N., Langslet G. i wsp. ODYSSEY FH I and FH II: 78 week results with alirocumab treatment in 735 patients with heterozygous familial hypercholesterolaemia. Eur. Heart J. 2015; 36: 2996-3003.

50. Ginsberg H.N., Rader J.J., Raal F.J. i wsp. ODDYSEY HIGH FH efficacy and safety of alirocumab in patients with severe heterozygous familial hypercholesterolemia [abstract]. Circulation 2014; 130: 2119.

51. Robinson J.G., Farnier M., Krempf M. i wsp. Efficacy and safety of alirocumab in reducing lipids and cardiovascular events. N. Engl. J. Med. 2015; 372: 1489-1499.

52. Hassan M. OSLER and ODDYSSEY LONG TERM: PCSK9 inhibitors on the right track of reducing cardiovascular events. Glob. Cardiol. Sci. Pract. 2015; 2015: 20.

53. Navarese E.P., Kołodziejczak M., Schulze V. i wsp. Effects of protein convertase subtilisin/kexin type 9 antibodies in adults with hypercholesterolemia. A systematic review and meta-analysis. Ann. Intern. Med. 2015; 163: 40-51.

54. Lipiński M.L., Benedetto U., Escarcega R.O. i wsp. The impact of protein convertase subtilisin-kexin type 9 serine protease inhibitors on lipid levels and outcomes in patients with primary hypercholesterolemia: a network meta-analysis. Eur. Heart J. 2016; 37: 536-545. 